\title{
The Democratic Simulation of the Public Space and Its Complex Human Relations
}

\author{
Wendy Montes Ponce, Esteban Sumano Sánchez, Otniel Josafat López Altamirano \\ Universidad Autónoma "Benito Juárez” de Oaxaca (UABJO), Oaxaca, México
}

\begin{abstract}
The public space is currently the product of a simulation of democracy, the subject of the present investigation. In the phenomenon, social aspects intervene that gestate labor, religious and political activities. The observation of urban behavior in historic centers was handled through the deductive method observing permitted or prohibitive areas of commercialization in the Historic Center of Oaxaca; it shows that it was determined by the reproduction of the urban simulation. The purpose was focused on the exploration of spatial utility and the normative models of urban practices and practices. The results revealed the public space is the product of negotiations that exhibit multiple inequalities: social strata, division of labor, political interests, religious and cultural expressions. Spatial projections are of: expropriation, distribution, donation, and resignation; from a domestic to industrial scale. The democratic simulation and its complex human relations multiplied the creeds and collective rituals, the proliferation of non-legal business and the dispute of the public space. It is concluded that those who administer and enforce civic policies and urban rules should promote solutions for coexistence; as a formative and attitudinal issue in the space that belongs to all of us.
\end{abstract}

Keywords: simulation, urbanism, politics, commerce, religion

\section{Introduction}

In the last years, the professionals of the diverse disciplinary fields have built-up efforts to define and give examples of urban concepts. Therefore, it has been clarified that the nature and the values, which were considered in the past as the principal basis, are no more updated to support the elementary functions of the responsible use of the public space.

\section{Foundational Aim of Urban Simulation}

The hypothesis which supports this paper is focused on the idea that the public spaces located in the historical centers are a product of a simulation of democracy where the official discourse is meant as a space for everyone, even though it is not officially established according to the Law. From our point of view, it is considered as a collective space in which the use of the space is defined as a particular use, which following the Law is stated like: "it is mine" and "my beloved ones", just as if it were a private property: "it is mine, it is

Wendy Montes Ponce, architecture/master, Facultad de Arquitectura "5 de Mayo", Universidad Autónoma "Benito Juárez" de Oaxaca (UABJO).

Esteban Sumano Sánchez, architecture/Ph.D., Facultad de Arquitectura "5 de Mayo", Universidad Autónoma "Benito Juárez" de Oaxaca (UABJO).

Otniel Josafat López Altamirano, digital design/master, Facultad de Arquitectura "5 de Mayo", Universidad Autónoma "Benito Juárez" de Oaxaca (UABJO). 
yours, it is ours", so it can only be used by our people. Any other idea opposed to "us" is meant as an invasion, to the won property.

\section{Methodological Considerations}

The observations of multiple studies on Historical Centers in the country encouraged the development of an evaluation which intended to find non-evident urban phenomena. Based on this, every state has determined the corresponding polygon to the Permitted or Prohibited Commercialization Zones.

The theorization about the conflicts for the space and urban order proposed by Emilio Duhau and Angela Giglia, both researchers on the urban and demographic studies in Colegio de México, was taken as a pertinent proposal for the verification of the hypothesis stated above. According to Duhau and Giglia's theory, the urban order must be understood as:

...el conjunto de normas y reglas tanto formales (pertenecientes a alguna jerarquía del orden jurídico) como convencionales a las que recurren los habitantes de la ciudad explícita o tácitamente en el desarrollo de las prácticas relacionadas con los usos y las formas de apropiación de los espacios y bienes públicos o de uso colectivo que, más allá de la vivienda, son los elementos constitutivos de la ciudad. ${ }^{1}$ (2004, p. 258)

\section{Study Development}

Every identified urban pattern is defined from its constitutive elements and its formal production relations. The subject matter here corresponds to the national public politics which result in a conflict in the use of the collective space. It is about an urban space characterized by social practices transformed into high contrast urban phenomena which stimulates concatenated behaviors among its occupants. This urban order is restricted into two kinds of legal norms: those which regulate the appropriation of the soil, its uses and the level of production, and those which regulate the urban practices restricted to official rules stated by the corresponding authorities. As a consequence, the conjugation of both normative typologies determines the inhabitable qualities of the urban spaces, the urban image of the place, and the homogeneity and heterogeneity of it.

It is important to consider that the spatial phenomena are stimulated by the sum of constant elements: the social dynamics, the level of existent relations among the citizens, the actions that every authority assumes to make the rules about the use of the space, the public goods, and the same morphology of the place be obeyed. All of these are opposed to the everyday urban phenomena, many of which are as a result of attitudinal facts, traditions, or social thoughts. Thereupon this public space is a disputed space understood as a space ruled by human expressions that correspond to a demonstration of territorial occupation, which is democratically doubtful.

The level in which every squared meter is dealt does not correspond to the established rules that "order" the spatial occupation. The results can be so contrasting to the same street that it could be observed the same heterogeneous practices of spatial disputes. The spatial use is determined according to the occupant or occupants' judgement. This heterogeneous phenomenon is the result of a non-legalized occupation system; it is ruled under the other model proposed by Duhau and Giglia which is established under urban uses and practices

\footnotetext{
1 Duhau, Emilio and Giglia, Ángela. "Conflictos por el espacio y el orden urbano". Revista sobre Estudios demográficos y Urbanos. Colegio de México, A. C. México, D. F., 2004. ISSN 0186-7210. “...the set of formal norms and rules (belonging to any hierarchy of the legal system) or the conventional ones use by the citizens explicitly or tacitly in the development of the practices related to the traditions and the forms of appropriation of the spaces and public goods or the collective use that, beyond the housing, are the constitutive elements of the city" (Translator's note).
} 
(my belongins, your belongins...our belongins) under which the globalization has introduced citizens' attitudes and aptitudes manifesting that today, the public space is a question of negotiation that shows disparities of multiple reasons - social, economic, politic, cultural, racial, gender. The centric places, such as Historical Centers permanently experiment changes like: land use, commercial occupation, demand of services and usage which usually are disputed according to social strata, work division, political interests which take to specific schedules and calendars. Specific actions that are projected are a space that is: expropriated, distributed, alternated, or declined. The regulations are not respected. The social law promotes the culture of cheater citizens, and its expression in the "everybody's space" has many nuances; it does not respect other people's rights to concentrate them in social sectors of well-established characteristics, from the domestic scale to the industrial one. The open space has its history before gradual change from the commercial to residential use, including the doubtful efficiency of the official regulation norms and control of it, under which there are given acute levels of urban complexity.

Commerce is one of the principal factors that stimulate the disputes of the space in all its modalities - expropriation, distribution, inheritance, resignation, predation. The necessity of: offering the products to be sold, having a safe and favorable space, besides a load and unload parking space, is one of the multiple modalities that conforms the contemporaneous condition of selling in the streets.

In the last 50 years, the street selling and the non-established commerce did not represent such a complex problem. This kind of commerce done by the street food and services vendors was performed in less than a one-squared meter space. The objective was to sell the products placed on a table, and the seller was sitting in a little chair protected by a kind of celling made with a piece of fabric. Its early history comes from the morning services practiced in the cities: the tamal seller, the shoeshiner, the gasoline seller, the newspaper seller, etc. However, as the schedules dispositions to commute to work in the precedent centuries changed, the informal commerce extended the permanence of these sellers now in open spaces. The exhibition of the products now was formal, and it was allowed to set other kinds of stands made of more resistant and easy-to-transport materials which were kept in the backyards of the houses and surrounding neighborhoods. This is the beginning of the informal commerce, where the integration of new stand owners turned into a highly problematic fact regarding the agreements between the municipal authorities and the leaders about the simulated law enforcement which regulates the occupation of the land use.

As the number of sellers multiplied, the concept of pedestrian walkway occupation changed to a much more complex phenomenon. Urban concepts such as wide of the street to a double lane and one of parking, were eliminated the same as the side-walk owning. The disputed space is projected in the assembling of the commercial paths; under which it is reproduced the phenomenon of supply and demand. There are a number of disputes owing to the differences between the legalized and the non-legalized sellers, who find any pretexts to have confrontations where, among themselves, they refer to each other as "the snobbish ones" and "the dirty, vulgar and violent ones".

This situation is not exclusive in the popular zones of the city; it also occurs in the bigger urban zones, but they look like with more exclusivity. The distribution of handy crafts or manufactured products increases through a subtle siren call. Without an exhibition support, the handy crafts are introduced as a consumption item to which it is attributed, not considering its monetary value, some intangible indexes related to the folkloric community myth. Taking advantage of the urban, traditional, and harmonic image, the owners of those business from this zone empower themselves and dispute the urban space through advertising resources. 
The business men from the zone of better economic resources expropriate square meters from the public space; it is about a benefit exercised from the use of the possible omissions or inaccuracies of the rules. It is also common to observe that the family relations enable the use of the space into the complex manifestations. Businessmen and street sellers take the sidewalks by setting appealing items so that their clients identify the right route to their stands. So, having breakfast, eating or having dinner, and observing an urban landscape from the principal portal of the main square, is one of the examples that significantly expresses phenomenon of expropriation of the collective space. These places concentrate banqueters, employees, pedestrians, singers, street sellers, and beggars. However, the occupation of the territory is not always performed in a democratic way. The geographical division of the city and its differences among social classes generates manifestations of possession. Businessmen and representatives of touristic business sectors confiscate spaces of the public street, and with this action, they obstruct parking lot spaces by setting temporal or permanent objects to do so, such as buckets, old chairs, or any kind of publicity. These are done so that the loading and unloading vehicles and tour transportations have a free space to park. It represents more than the $80 \%$ of the length of the block.

The concentration of specific activities; bureaucratic-municipal or state, or school kind, also have different kinds of disputing the public spaces. The occupation and liberation of these spaces in rush hours, allows to strength personal relations that determine the relay of the vehicles according to constant schedules, causing violent reactions against any "invader" who could park the vehicle in those places.

Even though, some of the administrative authorities and the ones from the private enterprise of the city determine the kind, amount, and scheduling of services that each one of their zones must have; their operation represents another kind of spatial occupation. Although this appropriation is temporary, the operation criteria of Federal Electricity Commission, Teléfonos de México, Sanitation Service, LP Gas, which are suppliers of commercial products, represent a messy operation difficult to re-structure in a short term.

The spatial empowerment is a psychological phenomenon which make these facts more problematic every time. If they are observed as a scientific study, they have to be developed from the inter and transdisciplinarity. The individual and collective interest of a disputed space is related to economic, social, politic, and cultural goods which have national, regional, and worldwide implications. The urban and architectonic examination may take us to peculiar answers that show us new parameters about constructive activities. Considering the urban territory where there has been done most of the analyzed phenomenon, the conclusions leave open other variables in the study that must be treated all at once, such as the dispute of the semirural space, which tends to reproduce the same schema as the ones in the big cities.

\section{Achievements and Results}

The observed phenomena indicate a disguised democracy of use. Urban phenomena generate the constant dispute, negotiation, expropriation, exchange of every squared meter that conforms the land. The emerging meanings respond to an urban reconceptualization not easy to homogenize. The strengths obtained by the political groups, civil associations, legally recognized foundations or unions, have showed the most powerful capacity of civic regulation in the space of the patrimonial city performed by the "los de abajo" (the villagers).

A possible solution to face the street vending phenomenon has been centered in the same core of the problem, whose root is of a social order. For this reason, it should not be ruled under the legal norms, but from the civic norms since it corresponds to a socio-behavioral product. This is a generational transmission fact learnt by those inhabitants who own the capacity to organize themselves, resist and negotiate the occupied 
public space. Anything can be neither progressive nor conclusive. According to Dr. Campos Salgado's opinion, since the individual and collective decisions are consequences of domain relations, then some domain practices are developed and applied by some social groups over other social groups, which is defined by him as "power discourse , , where the author shuffles off, in a certain way, to the forms learnt along the modern times, under which it was born the differences among the constitutive elements of the context, and the right of the appropriation of the public space.

The exposed discourses show the confirmation of the hypothesis that fostered this document. The public space in the object of study is the result of a democratic simulation broken by the official discourse which states that the right of urban occupation is seen as an egalitarian space for everybody. The hereby document is not to postpone the disputed space phenomenon, but to raise concerns among people who could put into practice an attitudinal change in the society who is involved direct or indirectly with public space, which naturally belongs to everybody.

\section{References}

Duhau, E., \& Giglia, A. (2004). Conflictos por el espacio y el orden urbano (Conflicts for the space and the urban order). Revista Sobre Estudios Demográficos y Urbanos (Magazine on Urban and Demographic Studies), 19(2), 257-288.

Duhau, E., \& Giglia, A. (2008). Las reglas del desorden, habitar la metrópoli (The rules of disorder, to inhabit the metropoly).

Siglo XXI. Coedited with Universidad Autónoma Metropolitana Azcapotzalco, México, D. F.

Giner, J. (2006). Antropología urbana (Urban anthopology). Argentina: Ariel.

Meneses, R. (2010). Professor Researcher in the Division of Juridical Studies of the Economy and Teaching Juridical Studies Center (División de Estudios Jurídicos del Centro de Investigación y Docencia Económicas), presented in a Permanent Seminar "Historical Center of Mexico City", a conference called: The Juridical Negotiation on the Right to the City: The Street Vendors and The Historical Center of Mexico City. 11th session, coordinated by the Programa de Maestría y Doctorado de la Universidad Nacional Autónoma de México.

Monguin, O. (2006). La condición urbana (The urban condition). Argentina: Paidós.

Rossi, U. (January-June 2003). Nápoles, ciudad democrática: La construcción del centro histórico como un espacio público. Economía, sociedad y territorio (Napoli, democratic city: The construction of the historic center as a public space. Economy, society and territory). Colegio Mexiquense, A. C. Mexico.

Salgado, C. (2005). Para leer la ciudad (To read the city). Universidad Autónoma Metropolitana (UAM) coedited with the Universidad Nacional Autónoma de México (UNAM), México, D. F.

\footnotetext{
${ }^{2}$ Campos Salgado. Para leer la ciudad. Universidad Autónoma Metropolitana en coedición con la Universidad Nacional Autónoma de México, México, D. F. 2005 (Campos Salgado. To Read the City. Universidad Autónoma Metropolitana in coedition with the Universidad Nacional Autónoma de México, México, D. F. 2005) (Translator's note).
} 